\title{
Use of in situ Mössbauer Spectroscopy and X-Ray Diffraction Techniques for the Characterization of Activated Fe-Ce Catalysts Employed in Fischer-Tropsch Synthesis
}

\author{
F.J. Pérez-Alonso ${ }^{1}$, M. Ojeda ${ }^{1}$, T. Herranz ${ }^{1}$, J.M. González-Carballo ${ }^{1}$, J.L.G. Fierro ${ }^{* 1}$, J.F. Bengoa ${ }^{2}$ \\ and S.G. Marchetti ${ }^{2}$
}

\author{
${ }^{I}$ Instituto de Catálisis y Petroleoquímica (CSIC), Marie Curie 2, 28049 Madrid, Spain; ${ }^{2}$ CINDECA, Facultad de Cien- \\ cias Exactas, Facultad de Ingeniería, UNLP, CONICET, Calle $47 N^{\circ}$ 257, 1900 La Plata, Argentina
}

\begin{abstract}
Several Fe-Ce catalysts for FT synthesis were prepared following two different methods: coprecipitation from $\mathrm{Fe}$ and $\mathrm{Ce}$ nitrate solutions and a physical mixture of pure $\mathrm{Fe}$ and $\mathrm{Ce}$ oxide precursors. Previously to $\mathrm{CO}$ hydrogenation, catalysts were activated in syngas $\left(50 \mathrm{ml} / \mathrm{min}, \mathrm{H}_{2} / \mathrm{CO}=2\right)$ at $553 \mathrm{~K}$ for $1 \mathrm{~h}$ at atmospheric pressure. The iron phases developed after activation pretreatment were identified by XRD and in situ Mössbauer spectroscopy with the objective to study the effect of the addition of cerium on the reduction behavior and catalytic properties of Fe systems. A good correlation between iron phases detected by both techniques was found. The results revealed that the cerium oxide in the samples prepared by coprecipitation produces two effects: (i) lower reduction rate leading to the metastable $\mathrm{Fe}_{1-\mathrm{x}} \mathrm{O}$ species, and (ii), a decrease in the crystallite size of the iron species upon increasing Ce-contents, as inferred from an increase in superparamagnetic species detected by in situ Mössbauer spectroscopy. Since iron carbides are the "real" active phases in FT synthesis, the stabilization of $\mathrm{Fe}_{1-\mathrm{x}} \mathrm{O}$ phase after activation is suggested to be responsible for the drop in catalytic activity in Fe-Ce catalysts prepared by coprecipitation during FT synthesis.
\end{abstract}

\section{INTRODUCTION}

The Fischer-Tropsch (FT) process is a route for producing sulphur- and aromatic-free liquid fuels, together with other chemical products (mainly alcohols) from syngas $\left(\mathrm{CO}+\mathrm{H}_{2}\right)$ mixtures. One of the challenges of the FT process is the search for flexibility in product distribution. Control of the FT conditions and catalyst promotion may result in high yields of gasoline, excellent quality diesel fuels, or high value linear $\alpha$-olefins (the most important feedstock for the production of chemicals). Although the changes in the operational variables (pressure, contact time, reactor selection or temperature) can be used to direct FT synthesis towards a desired target pool of products, in practice the gain in selectivity is insufficient. The best results have been found with the promotion of conventional FT catalysts (Fe or Co). Currently, typical iron-based catalysts are prepared by precipitation techniques and contain varying amounts of structural additive, such as silica or alumina, and chemical promoters, such as potassium and copper, which are known to increase overall FT activity and also facilitate the reduction of iron oxide, respectively. Some efforts have focused on the addition of Rare Earths (RE) on Fe-supported and bulk Fe FT catalysts $[1,2]$. The same promotional effect has been observed on the catalytic properties: i.e., higher syngas conversion, a higher olefin content and higher selectivity towards light fractions.

The aim of the present work was to provide some clues as to the effect of the addition of cerium on the catalytic

*Address correspondence to this author at the Instituto de Catálisis y Petroleoquímica (CSIC), Marie Curie 2, 28049 Madrid, Spain; Tel: +34 915854769; Fax: +34 915854760; E-mail: jlgfierro@icp.csic.es properties of Fe systems. A pure precipitated Fe was selected as the catalyst to be promoted. Several Fe-Ce catalysts (with different $\mathrm{Fe}$ :Ce atomic ratio) were prepared by coprecipitation from $\mathrm{Fe}$ and $\mathrm{Ce}$ nitrate solutions. The properties of the coprecipitated $\mathrm{Fe}-\mathrm{Ce}$ catalysts were compared with those of a mixed $\mathrm{Fe}-\mathrm{Ce}$ system prepared by physical mixture of pure $\mathrm{Fe}$ and $\mathrm{Ce}$ oxides. The iron phases present in the activated catalysts under $\mathrm{CO}+\mathrm{H}_{2}$ mixtures were characterized with a view to determining not only the nature of the active phases responsible for the FT synthesis, but also to understanding the role played by cerium oxide.

\section{EXPERIMENTAL}

A series of coprecipitated iron-cerium catalysts with 100 , $95,85,50$ and 0 at \% Fe metal (Ce balance) was prepared by batchwise coprecipitation under vigorous stirring from $1 \mathrm{M}$ aqueous solutions of $\mathrm{Fe}\left(\mathrm{NO}_{3}\right)_{3} .9 \mathrm{H}_{2} \mathrm{O}$ (Fluka puriss. p.a. ACS: $98-101 \%$ ) and $\mathrm{Ce}\left(\mathrm{NO}_{3}\right)_{3} \cdot 6 \mathrm{H}_{2} \mathrm{O}$ (Aldrich $99.99 \%$ ) with a $5.6 \mathrm{M} \mathrm{NH}_{4} \mathrm{OH}$ solution. Both solutions were added simultaneously at a constant rate of $50 \mathrm{ml} / \mathrm{h}$ by a perfusion pump (Becton Dickinson SE 400) to a precipitation batch initially containing $500 \mathrm{ml}$ of distilled water. Addition of the precipitating agent $\left(\mathrm{NH}_{4} \mathrm{OH}\right)$ was accomplished using a $\mathrm{pH}$ stationary device (Radiometer Copenhagen; ABU91 Autoburette), maintaining constant $\mathrm{pH}$ at 8.0 during precipitation. Temperature was kept at $343 \mathrm{~K}$. The precipitate thus obtained was aged for $16 \mathrm{~h}$ with the mother liquors, still under stirring at the reaction temperature and maintaining $\mathrm{pH}$ at 8.0. Then, the precipitate was filtered out and washed with successive portions of $400 \mathrm{ml}$ of distilled water at $323 \mathrm{~K}$. Henceforth, these will be referred to as the $100 \mathrm{Fe}, 95 \mathrm{Fe}$, $85 \mathrm{Fe}, 50 \mathrm{Fe}$ and $\mathrm{Ce}$ fractions. The precipitates were air-dried at $333 \mathrm{~K}$ for $24 \mathrm{~h}$. Another sample was prepared by physi- 
cally mixing the dried pure $\mathrm{Fe}$ and $\mathrm{Ce}$ precipitates. These precursors were mixed at a ratio required to obtain a mixed sample of Fe-Ce with $85 \%$ at Fe (this catalyst will be referred to as $\mathrm{PM} 85 \mathrm{Fe}$ ). All precursors were then calcined at $573 \mathrm{~K}$ under ambient air for $6 \mathrm{~h}$.

Powder X-ray diffraction (XRD) patterns were recorded in the $5-80^{\circ} 2 \theta$ range in the scan mode $\left(0.02^{\circ}, 2 \mathrm{sec}\right)$ using a Seifert 3000 XRD diffractometer equipped with a PW goniometer with Bragg-Brentano $\theta / 2 \theta$ geometry, an automatic slit, and a bent graphite monochromator. Mössbauer spectra were obtained at $298 \mathrm{~K}$ and $22 \mathrm{~K}$ in transmission geometry with a constant acceleration spectrometer. A source of ${ }^{57} \mathrm{Co}$ in the Rh matrix was used. All isomer shifts (IS) are referred to $\alpha$-Fe. Mössbauer spectra at low temperatures were obtained using a closed-cycle cryogenic system. Before characterization, samples were reduced in syngas $(50 \mathrm{ml} / \mathrm{min}$, $\mathrm{H}_{2} / \mathrm{CO}=2$ ) at $553 \mathrm{~K}$ for $1 \mathrm{~h}$ at atmospheric pressure. XRD patterns of the different samples were recorded after passivation of reduced samples with a flow of $\mathrm{O}_{2} / \mathrm{N}_{2}\left(1 \% \mathrm{O}_{2}, 100\right.$ $\mathrm{ml} / \mathrm{min}$ ) for $1 \mathrm{~h}$. Mössbauer spectra were obtained in a controlled atmosphere at 298 and $22 \mathrm{~K}$ after reduction of the different samples in a cell specially built for this purpose [3].

X-ray photoelectron spectroscopy (XPS) studies were performed on a VG Escalab $200 \mathrm{R}$ spectrometer equipped with a hemispherical electron analyzer and $\mathrm{Mg} \mathrm{K} \alpha$ (1253.6 $\mathrm{eV}) \mathrm{X}$ ray source. Some selected samples were treated in situ in the cell of the spectrophotometer. A pulse (around $50 \mathrm{kPa}$ ) of a mixture of $\mathrm{H}_{2} / \mathrm{CO} / \mathrm{N}_{2}(31 / 62 / 7$ molar ratio) was admitted. The sample was under this mixture at $673 \mathrm{~K}$ for $16 \mathrm{~h}$ and then cooled down to room temperature before being transferred to the analysis chamber for the recording of the XPS spectra. A certain energy region of the XPS spectrum was scanned a number of times in order to obtain a good signal to noise ratio. The binding energies (BE) were referenced by using the $\mathrm{C} 1 \mathrm{~s}$ peak $(284.6 \mathrm{eV})$ of spurious carbon as an internal standard. The areas of the peaks were computed by fitting the experimental spectra to Gaussian/Lorentzian curves after removal of the background (Shirley function). Surface atomic ratios were calculated from peak area ratios normalized by the corresponding atomic sensitivity factors [4].

The catalysts were tested in the $\mathrm{CO}$ hydrogenation reaction using a fixed-bed microreactor (stainless steel 316; length $150 \mathrm{~mm}$ and i.d. $9 \mathrm{~mm}$ ). The temperature of the reactor was measured with a K-type thermocouple buried in the catalytic bed. Flow rates were controlled using a Brooks 5850 TR Series mass flow controllers. The calcined samples (100 mg, 0.25-0.30 mm particle size) were diluted with SiC (ca. $2 \mathrm{~g} ; 0.25-0.30 \mathrm{~mm}$ particle size) to avoid hot-spots. First, the catalysts were activated in situ at $553 \mathrm{~K}$ (heating rate of $10 \mathrm{~K} / \mathrm{min})$ for $1 \mathrm{~h}$ in syngas $\left(50 \mathrm{ml} / \mathrm{min}, \mathrm{H}_{2} / \mathrm{CO}=2\right)$ at atmospheric pressure. The reactor was then cooled down to the reaction temperature and the system was pressurized to 1.01 $\mathrm{MPa}$. At least 10-12 h were necessary for steady-state to be reached. Product analysis was performed on-line with a gas chromatograph (HP 6890 Plus). Inorganic gases were analyzed in a Porapak Q (3 m x 1/8") packed column connected to a thermal conductivity detector. Hydrocarbons and oxygenated compounds were analyzed in a DB-1 capillary column $(60 \mathrm{~m} \times 0.25 \mathrm{~mm} \times 0.25 \mu \mathrm{m})$ connected to a flame ionization detector.

\section{RESULTS}

\section{XRD Characterization}

Fig. (1) shows the XRD patterns of the calcined precursors at $573 \mathrm{~K}$. The reflections can be assigned either to hematite, $\alpha-\mathrm{Fe}_{2} \mathrm{O}_{3}$ [5], or $\mathrm{c}-\mathrm{CeO}_{2}$ [6]. In the case of $100 \mathrm{Fe}$, only. $\alpha-\mathrm{Fe}_{2} \mathrm{O}_{3}$ reflections were observed although obviously those of $\mathrm{c}-\mathrm{CeO}_{2}$ in the case of Ce sample. Physically mixed sample (PM85Fe) displayed reflections from both phases. However, in the samples prepared by coprecipitation, the situation was not as simple.

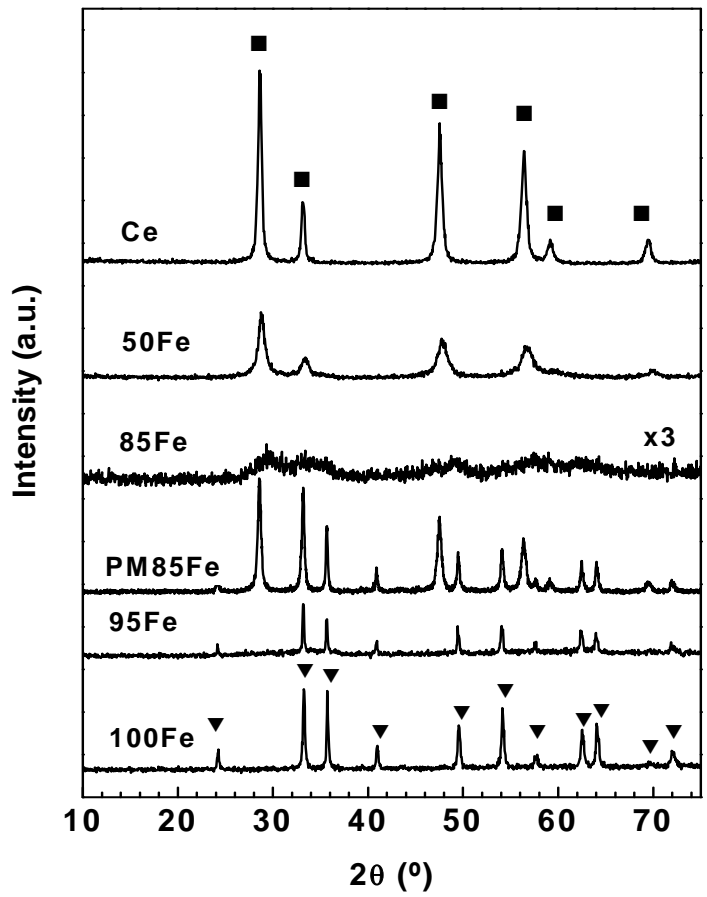

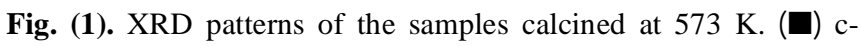
$\mathrm{CeO}_{2} ;(\boldsymbol{\nabla}) \alpha-\mathrm{Fe}_{2} \mathrm{O}_{3}$.

The $95 \mathrm{Fe}$ sample displayed reflections only from. $\alpha$ $\mathrm{Fe}_{2} \mathrm{O}_{3}$ while no diffraction from $\mathrm{Ce}$ oxide was detected. At the other end of the composition range, the $50 \mathrm{Fe}$ catalyst exhibited only reflections arising from $\mathrm{c}-\mathrm{CeO}_{2}$ whereas no reflections from the $\mathrm{Fe}$ phase were detected. Additionally, they were wider than those arising from the $\mathrm{c}-\mathrm{CeO}_{2}$ detected in the Ce sample and in PM85Fe catalyst precursor. The wider reflections indicate that the phases displayed smaller crystal size or microstrain (mainly variations in the lattice parameters due to the inhomogeneity of the composition of the phases formed during coprecipitation). In the case of the $85 \mathrm{Fe}$ sample, the low intensity of the reflections observed indicates poor crystallization of the sample. This hinders the straightforward assignation of the reflections to a particular phase but it seems that either $\alpha-\mathrm{Fe}_{2} \mathrm{O}_{3}$ or $\mathrm{c}-\mathrm{CeO}_{2}$, both with very small crystal size, would be present. In a previous work [7] these catalysts precursors were extensively studied and it was concluded that the coprecipitation procedure leads to the formation of solid solutions in which $\mathrm{Fe}$ or $\mathrm{Ce}$ are dissolved within a ceria or hematite structure, respectively. The main consequence of formation of solid solutions is that a direct $\mathrm{Fe}-\mathrm{Ce}$ interaction appears. This interaction, achieved only by coprecipitation, takes place through sharing of $\mathrm{O}$ anions de- 
fined by the $\mathrm{Fe}-\mathrm{O}-\mathrm{Ce}$ bonds formed either in the hematitelike mixed oxide or in the $\mathrm{c}-\mathrm{CeO}_{2}$-like mixed oxide.

The XRD patterns of the activated catalysts are depicted in Fig. (2). The reflections can be assigned to $\mathrm{Fe}_{3} \mathrm{O}_{4}$ (magnetite) [8], $\mathrm{Fe}_{1-\mathrm{x}} \mathrm{O}$ (wustite) [9] and $\mathrm{c}-\mathrm{CeO}_{2}$ [6]. In the case of the pure Fe sample $(100 \mathrm{Fe})$, only reflections from $\mathrm{Fe}_{3} \mathrm{O}_{4}$ are observed, while the PM85Fe sample only shows reflections of $\mathrm{Fe}_{3} \mathrm{O}_{4}$ and $\mathrm{c}-\mathrm{CeO}_{2}$. The situation is not as simple in the samples prepared by coprecipitation. Thus, the $95 \mathrm{Fe}$ sample shows reflections of $\mathrm{Fe}_{3} \mathrm{O}_{4}$ and $\mathrm{Fe}_{1-\mathrm{x}} \mathrm{O}$, whereas the $85 \mathrm{Fe}$ sample displays reflections not only of $\mathrm{Fe}_{3} \mathrm{O}_{4}$ and $\mathrm{Fe}_{1-\mathrm{x}} \mathrm{O}$ oxides, but also of $\mathrm{c}-\mathrm{CeO}_{2}$ oxide. All these reflections are very broad and of low intensity, suggesting a poor crystallization of these phases and/or a very low particle size. For the sample with the highest Ce concentration $(50 \mathrm{Fe})$ only reflections from $\mathrm{c}-\mathrm{CeO}_{2}$ are observed.

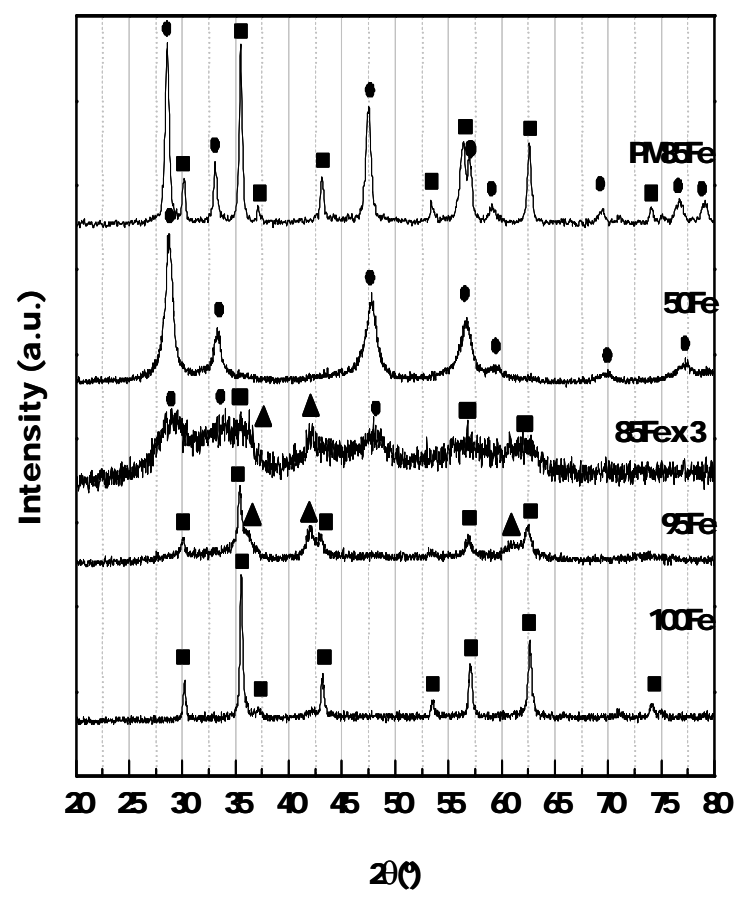

Fig. (2). XRD patterns of all the activated samples. $\mathrm{Fe}_{3} \mathrm{O}_{4}$ (magnetite, marked as $\boldsymbol{\square}$ ), $\mathrm{Fe}_{1-\mathrm{x}} \mathrm{O}$ (wustite, marked as $\boldsymbol{\Delta}$ ) and $\mathrm{c}-\mathrm{CeO}_{2}$ (marked as $\bullet$ ) .

\section{“in situ” Mössbauer Characterization}

Fig. (3) shows the Mössbauer spectra of the activated samples recorded at $298 \mathrm{~K}$. The Mössbauer spectra of the $100 \mathrm{Fe}$ and PM85Fe samples measured at $298 \mathrm{~K}$ clearly reveal the existence of only $\mathrm{Fe}_{3} \mathrm{O}_{4}$. Both spectra were fitted with two sextuplet characteristic of the $\mathrm{Fe}_{3} \mathrm{O}_{4}$ [10]. This situation changes in the samples prepared by coprecipitation. Thus, in the $95 \mathrm{Fe}$ sample, the two sextuplets assigned to magnetite show a lower intensity and an intense central signal is also observed. In the $85 \mathrm{Fe}$ and $50 \mathrm{Fe}$ samples, the magnetic signal disappears completely and a very broad central peak is the only visible signal. These fittings were performed using two doublets, and they probably correspond to superparamagnetic $\mathrm{Fe}_{3} \mathrm{O}_{4}$ and $\mathrm{Fe}_{1-\mathrm{x}} \mathrm{O}$ oxides, although a precise assignment is not possible owing to the lack of spectra recorded at low temperature.

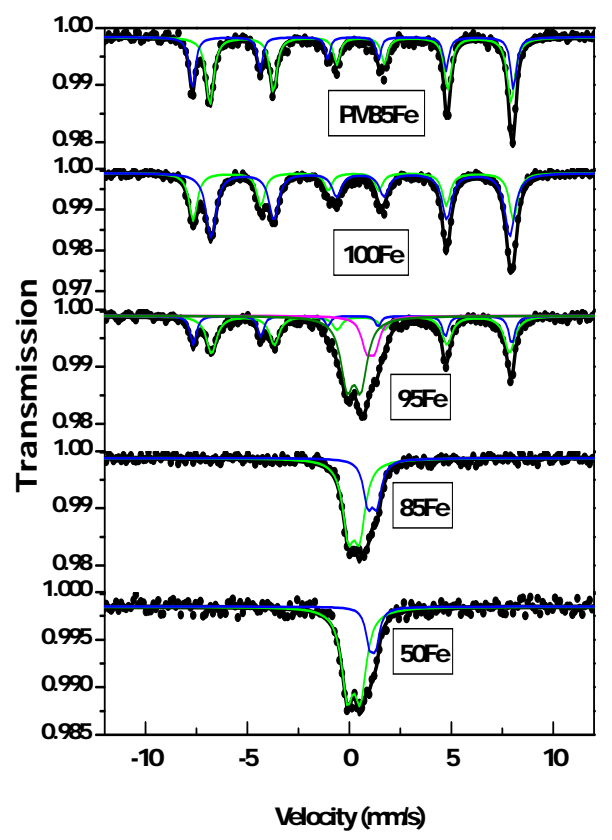

Fig. (3). Mössbauer spectra recorded at $298 \mathrm{~K}$ of activated samples.

The MS spectra recorded at $22 \mathrm{~K}$ (see Fig. 4) reveal a more complicated situation, because the $\mathrm{Fe}_{3} \mathrm{O}_{4}$ undergoes the Verwey transition. In this case, up to five different iron sites can be distinguished in agreement with literature [10]. Considering the similarity of the hyperfine parameters of the sites assigned to tetrahedral $\mathrm{Fe}^{3+}$ and octahedral-I $\mathrm{Fe}^{3+}$ (following Berry's nomenclature) and the complexity of our spectra, four sextuplets were used to fit the $\mathrm{Fe}_{3} \mathrm{O}_{4}$ below the Verwey transition (one of them is the mean of tetrahedral $\mathrm{Fe}^{3+}$ and octahedral-I $\mathrm{Fe}^{3+}$ ). The spectrum of $100 \mathrm{Fe}$ was used as a reference since at $298 \mathrm{~K}$ it only contains $\mathrm{Fe}_{3} \mathrm{O}_{4}$. The hyperfine parameters show satisfactorily agreement with other works [10] bearing in mind that crystallite size effects may be present in $100 \mathrm{Fe}$. These effects may be responsible for the decrease in the hyperfine fields of some sites.

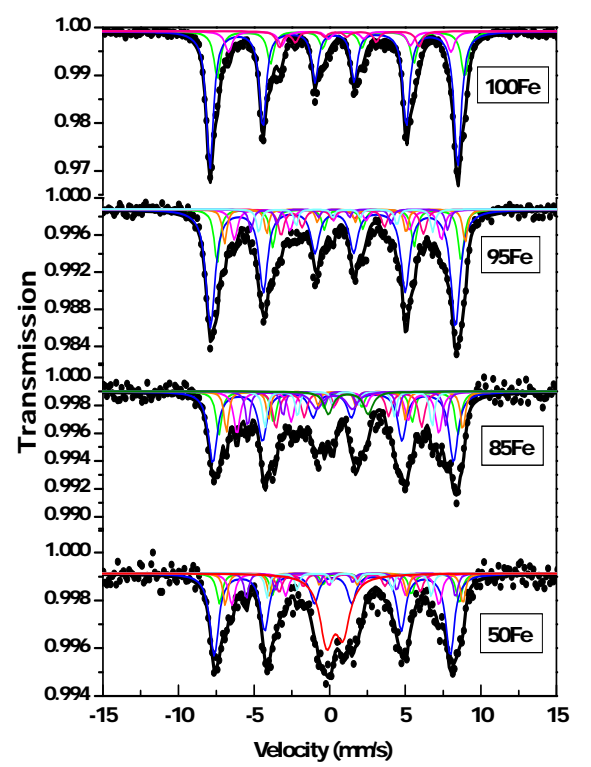

Fig. (4). Mössbauer spectra recorded at $22 \mathrm{~K}$ of activated $100 \mathrm{Fe}$, $95 \mathrm{Fe}, 85 \mathrm{Fe}$ and $50 \mathrm{Fe}$. 
Table 1. Hyperfine Parameters of MS Spectra Recorded at $22 \mathrm{~K}$ of the Samples Activated in a $\mathrm{CO}+\mathrm{H}_{2} \mathrm{Mixture}(50 \mathrm{ml} / \mathrm{min}$, $\left.\mathrm{H}_{2} / \mathrm{CO}=2\right)$ at $553 \mathrm{~K}$ for $1 \mathrm{~h}$ at Atmospheric Pressure

\begin{tabular}{|c|c|c|c|c|c|}
\hline & Parameters & $100 \mathrm{Fe}$ & $95 \mathrm{Fe}$ & $85 \mathrm{Fe}$ & $50 \mathrm{Fe}$ \\
\hline \multirow[t]{3}{*}{$\mathrm{Fe}_{3} \mathrm{O}_{4}: \mathrm{Fe}^{3+}$ tetrahedral and $\mathrm{Fe}^{3+}$ octahedral I } & $\mathrm{H}(\mathrm{T})$ & $50.9 \pm 0.1$ & $50.3 \pm 0.1$ & $49.5 \pm 0.1$ & $48.5 \pm 0.1$ \\
\hline & $\delta(\mathrm{mm} / \mathrm{s})$ & $0.41 \pm 0.01$ & $0.37 \pm 0.01$ & $0.31\left(^{*}\right)$ & $0.30 \pm 0.02$ \\
\hline & $2 \varepsilon(\mathrm{mm} / \mathrm{s})$ & $-0.04 \pm 0.01$ & $-0.09 \pm 0.02$ & $0.06 \pm 0.03$ & $-0.05 \pm 0.03$ \\
\hline \multirow[t]{3}{*}{$\mathrm{Fe}_{3} \mathrm{O}_{4}: \mathrm{Fe}^{3+}$ octahedral II } & $\mathrm{H}(\mathrm{T})$ & $50.8 \pm 0.1$ & $50.1 \pm 0.1$ & $49.1 \pm 0.1$ & $49.3 \pm 0.2$ \\
\hline & $\delta(\mathrm{mm} / \mathrm{s})$ & $0.89 \pm 0.02$ & $0.88 \pm 0.02$ & $0.84 \pm 0.02$ & $0.84 \pm 0.04$ \\
\hline & $2 \varepsilon(\mathrm{mm} / \mathrm{s})$ & $-0.08 \pm 0.03$ & $-0.29 \pm 0.03$ & $-0.30 \pm 0.04$ & $-0.18 \pm 0.08$ \\
\hline \multirow[t]{3}{*}{$\mathrm{Fe}_{3} \mathrm{O}_{4}: \mathrm{Fe}^{2+}$ octahedral I } & $\mathrm{H}(\mathrm{T})$ & $45.7 \pm 0.3$ & $42.5 \pm 0.2$ & $41.5 \pm 0.1$ & $42.5 \pm 0.2$ \\
\hline & $\delta(\mathrm{mm} / \mathrm{s})$ & $0.98 \pm 0.03$ & $1.04 \pm 0.02$ & $1.04 \pm 0.02$ & $0.82 \pm 0.03$ \\
\hline & $2 \varepsilon(\mathrm{mm} / \mathrm{s})$ & $-0.41(*)$ & $-0.79 \pm 0.04$ & $-0.78 \pm 0.04$ & $-0.67 \pm 0.06$ \\
\hline \multirow[t]{3}{*}{$\mathrm{Fe}_{3} \mathrm{O}_{4}: \mathrm{Fe}^{2+}$ octahedral II } & $\mathrm{H}(\mathrm{T})$ & $28.7 \pm 0.3$ & $29.2 \pm 0.2$ & $29.9 \pm 0.2$ & $29.0 \pm 0.4$ \\
\hline & $\delta(\mathrm{mm} / \mathrm{s})$ & $0.96(*)$ & $1.30 \pm 0.03$ & $1.29 \pm 0.02$ & $1.25 \pm 0.05$ \\
\hline & $2 \varepsilon(\mathrm{mm} / \mathrm{s})$ & $0.89(*)$ & $0.59 \pm 0.05$ & $0.15 \pm 0.04$ & $0.37 \pm 0.09$ \\
\hline \multirow[t]{3}{*}{$\mathrm{FeO}: \mathrm{Fe}^{3+}$ octahedral } & $\mathrm{H}(\mathrm{T})$ & ---- & $49.4 \pm 0.1$ & $48.6 \pm 0.1$ & $48.8 \pm 0.2$ \\
\hline & $\delta(\mathrm{mm} / \mathrm{s})$ & ---- & $0.83 \pm 0.02$ & $0.84 \pm 0.02$ & $0.87 \pm 0.03$ \\
\hline & $2 \varepsilon(\mathrm{mm} / \mathrm{s})$ & ---- & $0.56 \pm 0.04$ & $0.51 \pm 0.04$ & $0.39 \pm 0.06$ \\
\hline \multirow[t]{3}{*}{$\begin{array}{c}\mathrm{FeO}: \mathrm{Fe}^{2+} \text { octahedral associated to structural } \\
\text { defects }\end{array}$} & $\mathrm{H}(\mathrm{T})$ & ---- & $40.4 \pm 0.2$ & $40.7 \pm 0.1$ & $43.0 \pm 0.2$ \\
\hline & $\delta(\mathrm{mm} / \mathrm{s})$ & --- & $0.90 \pm 0.02$ & $1.03 \pm 0.02$ & $1.03(*)$ \\
\hline & $2 \varepsilon(\mathrm{mm} / \mathrm{s})$ & ---- & $1.01 \pm 0.05$ & $0.43 \pm 0.04$ & $0.98 \pm 0.06$ \\
\hline \multirow[t]{3}{*}{ FeO: $\mathrm{Fe}^{2+}$ bulk octahedral } & $\mathrm{H}(\mathrm{T})$ & --- & $35.8 \pm 0.2$ & $34.4 \pm 0.1$ & $33.7 \pm 0.2$ \\
\hline & $\delta(\mathrm{mm} / \mathrm{s})$ & ---- & $1.19 \pm 0.02$ & $1.27 \pm 0.02$ & $1.25 \pm 0.03$ \\
\hline & $2 \varepsilon(\mathrm{mm} / \mathrm{s})$ & ---- & $-0.05 \pm 0.05$ & $0.17 \pm 0.04$ & $0.30 \pm 0.06$ \\
\hline \multirow[t]{2}{*}{ Doublet $\mathrm{Fe}^{3+}$ of $\mathrm{FeO}$ and/or $\mathrm{Fe}_{3} \mathrm{O}_{4}$} & $\Delta(\mathrm{mm} / \mathrm{s})$ & --- & --- & $2.3 \pm 0.2$ & $1.08 \pm 0.05$ \\
\hline & $\delta(\mathrm{mm} / \mathrm{s})$ & ---- & ---- & $0.4 \pm 0.1$ & $0.45 \pm 0.04$ \\
\hline \multirow[t]{2}{*}{ Doublet $\mathrm{Fe}^{2+}$ of $\mathrm{FeO}$ and/or $\mathrm{Fe}_{3} \mathrm{O}_{4}$} & $\Delta(\mathrm{mm} / \mathrm{s})$ & ---- & ---- & $2.6 \pm 0.1$ & --- \\
\hline & $\delta(\mathrm{mm} / \mathrm{s})$ & ---- & ---- & $1.33 \pm 0.06$ & ---- \\
\hline
\end{tabular}

(*)Parameter values fixed in the fitting procedure.

Table 2. Catalytic Properties of Fe-Ce Catalysts in Fischer-Tropsch Synthesis. (CO Conversion was Close to 2.5\%)

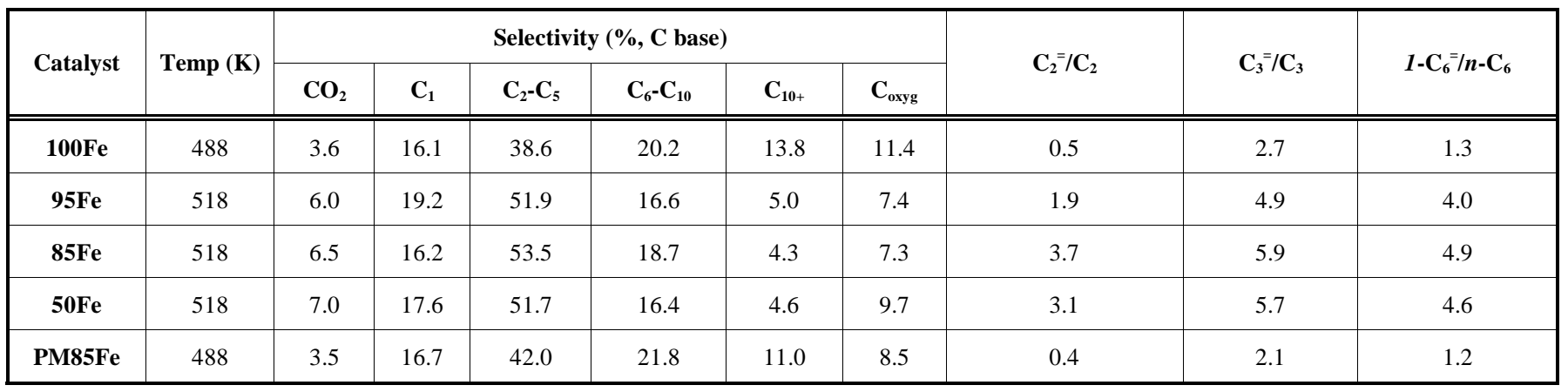


In the $95 \mathrm{Fe}, 85 \mathrm{Fe}$ and $50 \mathrm{Fe}$ samples, MS spectra at $22 \mathrm{~K}$ are very complex, and they display more signals than $100 \mathrm{Fe}$. If the doublet present at $298 \mathrm{~K}$ corresponded to $\mathrm{Fe}_{1-\mathrm{x}} \mathrm{O}$, as was mentioned above, then at $22 \mathrm{~K}$ three magnetic sites could be present: octahedral $\mathrm{Fe}^{2+}$ associated with lattice defects; bulk octahedral $\mathrm{Fe}^{2+}$, and octahedral $\mathrm{Fe}^{3+}$ coming from the lack of stoichiometry of the oxide [11]. In keeping with this argument, the spectra of $95 \mathrm{Fe}, 85 \mathrm{Fe}$ and $50 \mathrm{Fe}$ at $22 \mathrm{~K}$ were fitted with seven sextets: four of them belonging to $\mathrm{Fe}_{3} \mathrm{O}_{4}$ and the three others to $\mathrm{Fe}_{1-\mathrm{x}} \mathrm{O}$. Despite the complexity of these spectra, an acceptable agreement between the hyperfine parameters obtained by fitting (see Table 1) and the values reported in the literature was obtained [10,11]. It can thus be concluded that two different iron species are present in the $95 \mathrm{Fe}, 85 \mathrm{Fe}$ and $50 \mathrm{Fe}$ samples: $\mathrm{Fe}_{3} \mathrm{O}_{4}$ and $\mathrm{Fe}_{1-\mathrm{x}} \mathrm{O}$. These results are in agreement with the XRD data. Upon comparing these results with those obtained with $100 \mathrm{Fe}$ and PM85Fe, this different behavior can be attributed to the presence of $\mathrm{Ce}$ in very close interaction with iron. Finally, for the $85 \mathrm{Fe}$ and $50 \mathrm{Fe}$ samples a central signal in the fitting assigned to iron species $\left(\mathrm{Fe}_{3} \mathrm{O}_{4}\right.$ and/or $\left.\mathrm{Fe}_{1-\mathrm{x}} \mathrm{O}\right)$ in the superparamagnetic regime was required.

\section{Catalytic Activity}

The results concerning the $\mathrm{CO}$ hydrogenation reaction over the Fe-Ce catalysts are shown in Table 2 . The catalytic performance is compared at the same $\mathrm{CO}$ conversion level (around 2.5\%) through selection of the reaction temperature. Incorporation of $\mathrm{Ce}$ to a conventional Fe-based FT catalyst $(100 \mathrm{Fe})$ decreased its catalytic activity; a higher reaction temperature (ca. $30 \mathrm{~K}$ ) was required for the Ce-promoted catalysts in order to achieve a similar conversion. A similar activity and selectivity of $100 \mathrm{Fe}$ was observed for the sample prepared by physical mixing (PM85Fe). Nevertheless, the most remarkable result is that $\mathrm{Ce}$ incorporation to iron oxide led to a change in product selectivity. As a result of the addition of $\mathrm{Ce}$ in the coprecipitated samples, two effects were observed: (i), a higher water-gas shift activity (higher $\mathrm{CO}_{2}$ selectivity), and (ii), a higher product olefinicity. Thus, the 1-hexene/n-hexane ratio increased 3-4-fold for the $\mathrm{Ce}$ promoted catalysts. The increase in the 1-olefin/n-paraffin ratio was not affected by the higher temperature at which the activity was measured. In fact, olefinicity has been shown to increase with temperature and conversion for catalysts with basic precursors [12]. Finally, a shift in selectivity towards lighter products (higher selectivity to the $\mathrm{C}_{2}-\mathrm{C}_{5}$ fraction at the expense of products with more than 6 carbon atoms) was also observed.

\section{DISCUSSION}

The structural information about the Ce-Fe-O systems derived from the XRD data agrees satisfactorily with that provided by MS. In the case of the $100 \mathrm{Fe}$ and PM85Fe samples only $\mathrm{Fe}_{3} \mathrm{O}_{4}$ was detected, while in the $95 \mathrm{Fe}$ and $85 \mathrm{Fe}$ samples both $\mathrm{Fe}_{3} \mathrm{O}_{4}$ and $\mathrm{Fe}_{1-\mathrm{x}} \mathrm{O}$ were observed by XRD and by MS. However, for the $50 \mathrm{Fe}$ sample only a c- $\mathrm{CeO}_{2}$ crystalline phase was detected. The absence of diffraction lines of iron oxides points to the presence of poor crystallization and/or to particles of sizes lower than the detection limit of the XRD technique, i.e. ca. $4 \mathrm{~nm}$. Notwithstanding, the MS spectra revealed the presence of $\mathrm{Fe}_{3} \mathrm{O}_{4}$ and $\mathrm{Fe}_{1-\mathrm{x}} \mathrm{O}$ oxides for the $95 \mathrm{Fe}$ and $85 \mathrm{Fe}$ samples. The important contribution of superparamagnetic phases at the lowest temperature $(22 \mathrm{~K})$ indicates a small particle size for the iron oxides.

The XRD and MS results of samples prepared by coprecipitation showed that cerium oxide incorporation results not only in the stabilization of metastable species $\left(\mathrm{Fe}_{1-\mathrm{x}} \mathrm{O}\right)$ but also decreases, to a significant extent, the crystallite size of the iron species present. It is well documented that the reduction of bulk hematite $\left(\alpha-\mathrm{Fe}_{2} \mathrm{O}_{3}\right)$, and consequently of unsupported catalysts $[13,14]$, proceeds via magnetite and wustite to metallic iron. However, the formation of wustite cannot be observed because it is metastable below $893 \mathrm{~K}$, at which temperature it desproportionates into $\mathrm{Fe}_{3} \mathrm{O}_{4}$ and $\mathrm{Fe}^{0}$.

It has been reported [15-19] that $\mathrm{Fe}_{1-\mathrm{x}} \mathrm{O}$ can be stabilized in iron supported catalysts below the critical temperature by interaction with the support through the formation of mixed oxides. In a previous work [7], we observed a close Fe-O-Ce interaction in the precursor oxides prepared by coprecipitation, in which depending on the composition- a Fe-Ce solid solution with a hematite-like or ceria-like structure is developed. It seems that this close Fe-Ce interaction persists after the activation procedure, stabilizing the formation of $\mathrm{Fe}_{1-\mathrm{x}} \mathrm{O}$ in those samples $(50 \mathrm{Fe}, 85 \mathrm{Fe}$ and $95 \mathrm{Fe}$ ) and changing the catalytic properties with respect to $100 \mathrm{Fe}$ and $\mathrm{PM} 85 \mathrm{Fe}$, where $\mathrm{Fe}_{1-\mathrm{x}} \mathrm{O}$ was not observed. A lower activity was observed for the samples prepared by coprecipitation where $\mathrm{Fe}_{1-\mathrm{x}} \mathrm{O}$ is stabilized. It seems that this stabilization produces a lower reducibility of iron oxide to iron carbides and hence a lower activity. Similar results have been reported for $\mathrm{Fe}$ supported catalysts [20], where the $\mathrm{Fe}_{1-\mathrm{x}} \mathrm{O}$ phase was also observed.

In an attempt to substantiate the above hypothesis, some selected samples $(95 \mathrm{Fe}$ and $100 \mathrm{Fe})$ were subjected to reductive treatments with $\mathrm{H}_{2} / \mathrm{CO}$ mixture at $673 \mathrm{~K}$ for $16 \mathrm{~h}$ prior to recording XPS spectra. A higher temperature than catalyst activation temperature was selected for obtaining iron carbides in the samples and testing reducibility of catalysts at similar conditions than FT synthesis. The corresponding Fe $2 \mathrm{p}$ region of $95 \mathrm{Fe}$ and $100 \mathrm{Fe}$ catalysts is shown in Fig. (5).

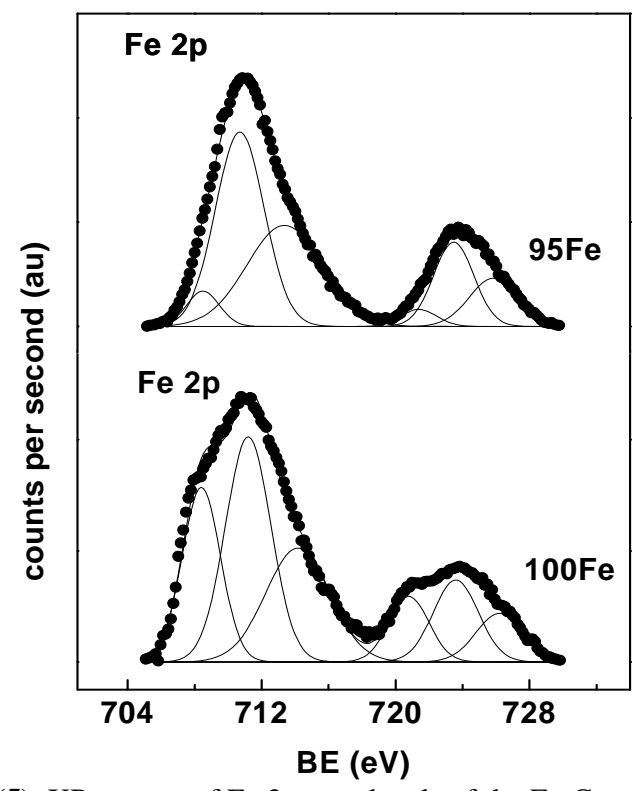

Fig. (5). XP spectra of Fe 2p core levels of the Fe-Ce catalysts after in situ treatments with $\mathrm{H}_{2} / \mathrm{CO}$ at $673 \mathrm{~K}$ for $16 \mathrm{~h}$. 
For the sake of simplicity, spectra were fitted to a characteristic $\mathrm{Fe}^{3+}$ doublet although it is also possible to include a $\mathrm{Fe}^{2+}$ doublet what would correspond to the presence of $\mathrm{Fe}_{3} \mathrm{O}_{4}$ and/or $\mathrm{Fe}_{1-\mathrm{x}} \mathrm{O}$. This conclusion is inferred from a lower binding energy $(711.0 \mathrm{eV})$ and higher FWHM observed that usual values observed in bibliography for $\mathrm{Fe}^{3+}$ in $\mathrm{Fe} 2 \mathrm{p}_{3 / 2}$ region [21]. However it is noticeable that XPS spectra recorded needs an additional species to be fitted. The binding energy values $(708.5 \mathrm{eV})$ of the additional peak in $\mathrm{Fe} 2 \mathrm{p}_{3 / 2}$ region corresponding to iron carbide species [21-23]. In this sense it is very remarkable that the relative abundance of iron carbides respect $\mathrm{Fe}^{3+}-\mathrm{Fe}^{2+}$ species is higher for $100 \mathrm{Fe}$ sample in contrast to $95 \mathrm{Fe}$ sample.

Therefore, the XPS results confirm the lower reducibility of iron oxides in $\mathrm{Fe}-\mathrm{Ce}$ catalysts by the presence of $\mathrm{Fe}_{1-\mathrm{x}} \mathrm{O}$ phase and then it justifies their lower catalytic activity in FT synthesis.

On the other hand, an increase in selectivity towards light $\alpha$-olefins was observed with the samples prepared by coprecipitation. If the effect of $\mathrm{Ce}$ is similar to that reported for other alkali-promoted iron catalysts [24,25], the observed effects for the Ce-promoted catalysts can be rationalized. We propose that the basic character of the $\mathrm{Ce}$ ions involves an increase in electronic density of the Fe sites, with a subsequent depletion in the amount of hydrogen that can be chemisorbed. This decrease in the hydrogen available on the catalyst surface results in the inhibition of the hydrogenation activity and therefore in an enhancement of product olefinicity.

A lower $\mathrm{H}_{2}$ chemisorption has also been reported [26] when increasing the proportion of $\mathrm{Fe}_{1-\mathrm{x}} \mathrm{O}$ with respect to the $\mathrm{Fe}_{3} \mathrm{O}_{4}$ phase, such that the stabilization of $\mathrm{Fe}_{1-\mathrm{x}} \mathrm{O}$ in $\mathrm{Ce}-$ promoted catalysts prepared by coprecipitation could be the reason for the decrease in hydrogen availability on the catalyst surface, and hence the increases in olefin selectivity. However, it may be assumed that a depletion of the availability of surface hydrogen also causes the formation of heavier product (shift to longer hydrocarbons). This is not the case of the Ce promoted-Fe catalysts addressed here since a lower growth probability factor was obtained and a higher proportion of $\mathrm{C}_{2}-\mathrm{C}_{5}$ fraction was observed. A similar result was reported by Wang, et al. [1], who attributed the shift to lighter products to the smaller size of the Fe ensembles caused by the Rare Earth promotion. Smaller active ensembles cannot accommodate large intermediates and hence the probability growth is inhibited.

\section{ACKNOWLEDGEMENTS}

Financial support from MCyT (Spain) under grant MAT2001-2215-CO3-01 is acknowledged. SGM and JFB acknowledge financial support from CONICET, ANPCyT, UNLP and CICPBA.

\section{REFERENCES}

[1] Wang D, Cheng X, Huang Z, Wang X, Peng S. Role of rare earth oxides and thoria as promoters in precipitated iron-based catalysts for Fischer-Tropsch synthesis. Appl Catal 1991; 77: 109-22.
[2] Cheng K, Yan Q. CO hydrogenation over zirconia supported iron catalysts promoted with rare earth oxides. Appl Catal A Gen 1997; 158: 215-23.

[3] Marchetti SG, Bengoa JF, Cagnoli MV, et al. A controlled atmosphere cell for a Mössbauer closed-cycle refrigerator. Meas Sci Tech 1996; 7: 758-62.

[4] Wagner CD, Davis LE, Zeller MV, Taylor JA, Raymond RH, Gale LH. Empirical atomic sensitivity factors for quantitative-analysis by electron-spectroscopy for chemical analysis. Surf Interface Anal 1981; 3: 211-25.

[5] Cornell RM, Schwertmann U. The Iron Oxides: Structure, Properties, Reactions and Uses VCH Publishers. New York 1996.

[6] JCPDS, X-ray powder diffraction files, Joint Committee for Powder Diffraction Standards. Swarthmore, PA, 1975. Card number 78694.

[7] Pérez-Alonso FJ, López Granados M, Ojeda M, et al. Chemical structures of coprecipitated $\mathrm{Fe}-\mathrm{Ce}$ mixed oxides. Chem Mater 2005; 17: 2329-39.

[8] JCPDS, X-ray powder diffraction files, Joint Committee for Powder Diffraction Standards. Swarthmore, PA, 1975. Card number 7533.

[9] JCPDS, X-ray powder diffraction files, Joint Committee for Powder Diffraction Standards. Swarthmore, PA, 1975. Card number 6615.

[10] Berry FJ, Skinner S, Thomas MF. ${ }^{57} \mathrm{Fe}$ Mössbauer spectroscopic examination of a single crystal of $\mathrm{Fe}_{3} \mathrm{O}_{4}$. J Phys: Conden Matter 1998; 10: 215-20.

[11] Wilkinson C, Cheetman AK, Long GJ, Battle PD, Hope DAO. Polarized neutron-diffraction and Mossbauer-effect study of the magnetic ordering in wustite. Inorg Chem 1984; 23: 3136-41.

[12] van der Laan GP, Beenackers AACM. Kinetics and Selectivity of the Fischer-Tropsch Synthesis: A Literature Review. Catal Rev-Sci Eng 1999; 41: 255-348.

[13] Kock AJHM, Fortuin HM, Geus JW. The reduction behavior of supported iron catalysts in hydrogen or carbon. J Catal 1985; 96: 261-75.

[14] Gao X, Shen J, Hsia Y, Chen Y. Reduction of supported iron oxide studied by temperature-programmed reduction combined with Mössbauer spectroscopy and X-ray diffraction J. Chem Soc Faraday Trans 1993; 89: 1079-84.

[15] Cagnoli MV, Marchetti SG, Gallegos NG, Alvarez AM, Mercader RC, Yeramián AA. Influence of the support on the activity and selectivity of high dispersion Fe catalysts in the Fischer-Tropsch reaction. J Catal 1989; 123: 21-30.

[16] Wielers AFH, Kock AHJM, Hop CECA, J.W. Geus JW, van der Kraan AMJ. The reduction behavior of silica-supported and alumina-supported iron catalysts-A Moosbauer and infared spectroscopy. J Catal 1989; 117: 1-18.

[17] Huang YY, Anderson JR. Reduction of supported iron catalysts studied by Mossbauer-spectroscopy. J Catal 1975; 40: 143-53.

[18] Hobson MC, Gager HM, Moosbauer effect studies of chemisorption-titration of surfaces of iron catalysts with polar molecules. J Colloid Interface Sci 1970; 34: 357.

[19] Yuen S, Chen Y, Kubsh JE, Dumesic JA, Topsoe N, Topsoe H. Metal-oxide support interactions in silica-supported iron-oxide catalysts probed by nitric-oxide adsorption. J Phys Chem 1982; 86: 3022-32.

[20] Jin Y, Datye AK. Phase transformations in iron Fischer-Tropsch catalysts during temperature-programmed reduction. J Catal 2000; 196: 8-17.

[21] Bonnet F, Ropital F, Lecour P, et al. Study of the oxide/carbide transition on iron surfaces during catalytic coke formation. Surf Interface Anal 2002: 34; 418-22.

[22] Shabanova N, Trapeznikov VA. Study of electronic-structure of $\mathrm{Fe} 3 \mathrm{C}, \mathrm{Fe} 3 \mathrm{~A} 1$ and Fe3SI by x-ray photoelectron spectroscopy. J Electron Spectrosc 1975; 6: 297-307. 
[23] Kuivila CS, Butt JB, Stair PC. Characterization of surface species on iron synthesis catalysts by $\mathrm{x}$-ray photoelectron spectroscopy. Appl Surf Sci 1988; 1-2: 99-121.

[24] Jager B, Espinoza R. Advances in low temperature Fischer-Tropsch synthesis. Catal Today 1995; 23: 17-28.
[25] Kölbel H, Ralek M. The Fischer-Tropsch Synthesis in the Liquid phase Catal. Rev-Sci Eng 1980; 21: 225-74.

[26] Huazhang L, Caibo L, Xiaonian L, Yaqing C. Effect of an Iron Oxide Precursor on the $\mathrm{H}_{2}$ Desorption Performance for an Ammonia Synthesis Catalyst. Ind Eng Chem Res 2003; 42: 1347-9.

(C) Pérez-Alonso et al.; Licensee Bentham Open.

This is an open access article distributed under the terms of the Creative Commons Attribution License (http://creativecommons.org/licenses/by/2.5/), which permits unrestrictive use, distribution, and reproduction in any medium, provided the original work is properly cited. 